\title{
PURIFICATION AND CHARACTERIZATION OF GLUTAMINE SYNTHETASE FROM ALKALOPHILIC BACILLUS No. 170
}

\author{
KINUKO KIMURA, ${ }^{*}$ EIICHI TANAKA, ${ }^{1}$ AND YOSHIO NAKANO ${ }^{2}$ \\ Laboratory of Biochemistry, College of Science, Rikkyo (St. Paul's) University, \\ Toshima-ku, Tokyo 171, Japan
}

(Received March 15, 1995; Accepted May 23, 1995)

\begin{abstract}
Glutamine synthetase from an alkalophilic Bacillus No. 170 was purified to homogeneity from cells grown in synthetic medium at $\mathrm{pH}$ 9.0. The purified enzyme had a molecular weight of 600,000 and a subunit size of 50,000 , similar to the enzymes from Bacillus subtilis and Bacillus cereus. Either $\mathrm{Mg}^{2+}$ or $\mathrm{Mn}^{2+}$ activated the enzyme; however, the highest activity was obtained when $20 \mathrm{mM} \mathrm{Mg}^{2+}$ with $0.2 \mathrm{mM} \mathrm{Mn}^{2+}$ were added to the assay mixture. The peculiar divalent cation dependency of the glutamine synthetase was similar to that of other Bacillus enzymes but differed from that of the enteric bacteria enzymes. The kinetic properties of the enzyme, such as optimum $\mathrm{pH}, K_{\mathrm{m}}$ for each substrate, $V_{\max }$ values, and inhibition by glutamine, were similar to those in the case of other Bacillus enzymes. The enzyme from this alkalophilic Bacillus was modified by iodoacetoamide or the ATP analog, 5'-p-fluorosulfonyl benzoyladenosine (FSBA). Only $\mathrm{Mg}^{2+}$-dependent activity was decreased by iodoacetamide, whereas each of the $\mathrm{Mn}^{2+}-, \mathrm{Mg}^{2+}$, and $\mathrm{Mg}^{2+}$ plus $\mathrm{Mn}^{2+}$-dependent activities was decreased with FSBA. The sequence of the $\mathrm{NH}_{2}$-terminal 20 amino acids of alkalophilic Bacillus glutamine synthetase was similar to those of other Bacillus enzymes.
\end{abstract}

Glutamine synthetase [L-glutamate: ammonia ligase (ADP-forming) EC 6.3.1.2] is an important enzyme in nitrogen metabolism and ammonia assimilation in many prokaryotes, eukaryotes, and archaebacteria. Consequently, the enzyme is subject to a variety of control mechanisms, and its regulation has been extensively studied in Escherichia coli and some enteric bacteria $(11,21,23)$. In these bacteria,

* Address reprint requests to: Dr. Kinuko Kimura, Laboratory of Biochemistry, College of Science, Rikkyo University, 3-34-1 Nishi-ikebukuro, Toshima-ku, Tokyo 171, Japan.

Present addresses: ${ }^{1}$ Laboratory for Biological Research, Asahi Chemical Industry Co., Ltd., Tagata-gun, Shizuoka 410-23, Japan; ${ }^{2}$ Department of Preventive Dentistry, Kyushu University Dental School, Higashi-ku, Fukuoka 812-82, Japan. 
the enzymatic activity is regulated by a cascade of reactions culminating in either adenylylation or deadenylylation of each dodecameric subunit of the enzyme, depending upon the state of nitrogen availability $(5,14)$. In contrast, there is no evidence that the Bacillus subtilis glutamine synthetase is regulated by reversible adenylylation although it appears that the mechanisms involved are different from those in $E$. coli and other enterics. In earlier papers, we reported the isolation and characterization of the glutamine synthetase from both Bacillus cereus and Bacillus subtilis $(12,13)$, the putative amino acid sequence from the DNA sequence of each gene $(16,18)$, and the determination of the substrate binding sites by chemical modification $(15,17,24)$. To confirm the unique characteristic of the glutamine synthetase from these spore-forming bacteria, we have been investigating nitrogen metabolism in alkalophilic Bacillus. To understand the physiology of growth and the nitrogen metabolism in the alkalophilic Bacillus, we purified glutamine synthetase from cells grown at pH 9.0. We report here that the glutamine synthetase isolated from alkalophilic Bacillus No. 170 closely resembles those of other Bacillus enzymes in its catalytic properties and $\mathrm{N}$-terminal amino acid sequence.

\section{MATERIALS AND METHODS}

Bacterial strains and culture conditions. Alkalophilic Bacillus No. 170 was grown aerobically to the early stationary phase at $37^{\circ} \mathrm{C}$ in modified alkaline medium ( $\mathrm{pH} 9.0)(8)$ with glucose $(11 \mathrm{~mm})$-glutamate $(30 \mathrm{~mm})$-glycine $(1.3 \mathrm{~mm})$ as the carbon and nitrogen sources.

Assay method. Glutamine synthetase activity was measured by the biosynthetic or $\gamma$-glutamyltransferase assays as described previously $(13,17)$. The standard biosynthetic assay mixture, in a final volume of $1.0 \mathrm{ml}$, contained $100 \mathrm{~mm}$ imidazole- $\mathrm{HCl}$ buffer, $5 \mathrm{~mm}$ ATP, $100 \mathrm{~mm}$ L-glutamate, $10 \mathrm{~mm}$ ammonia, divalent cation, and sufficient enzyme. As the divalent cations, $5 \mathrm{mM} \mathrm{MnCl}, 20 \mathrm{mM} \mathrm{MgCl}_{2}$, or $0.2 \mathrm{mM} \mathrm{MnCl} 2$ plus $20 \mathrm{mM} \mathrm{MgCl}_{2}$ were added for assay of $\mathrm{Mn}^{2+}-, \mathrm{Mg}^{2+}-$, and $\mathrm{Mg}^{2+}$ plus $\mathrm{Mn}^{2+}$-dependent activity, respectively. The $\mathrm{pH}$ of the buffer was 8.0 for $\mathrm{Mg}^{2+}$-, 7.85 for $\mathrm{Mg}^{2+}$ plus $\mathrm{Mn}^{2+}$-, and 6.4 for $\mathrm{Mn}^{2+}$-dependent assay. Each reaction mixture was incubated at $37^{\circ} \mathrm{C}$ for $10 \mathrm{~min}$. Specific activities are expressed as $\mu \mathrm{mol}$ of phosphate formed per minute per milligram protein. Protein in crude extracts was measured by the biuret method with bovine serum albumin as a standard. With the pure enzyme, the protein was determined either by the method of Lowry or from the absorbance at $280 \mathrm{~nm}$. Preparation of rabbit antisera for Bacillus subtilis glutamine synthetase was described previously (13). Each glutamine synthetase from $B$. subtilis or Escherichia coli was purified from E. coli YMC11 harboring pSGS2 (9) or pEGS1. Each plasmid contained the $g \ln$ A gene of B. subtilis or E. coli, respectively.

Purification of glutamine synthetase from alkalophilic Bacillus No. 170. Glutamine synthetase was purified from cells grown at $\mathrm{pH} 9.0$, according to the modified method previously described in Bacillus cereus enzyme (13). Cells (14 g 
wet weight) were suspended in four times their volume of buffer containing $50 \mathrm{mM}$ Tris- $\mathrm{HCl}$ ( $\mathrm{pH} 7.2$ ), $0.1 \mathrm{mM}$ EDTA, and $1 \mathrm{mM} \mathrm{MnCl}_{2}$. After rupture by sonication, crude extract was prepared by centrifugation at $20,000 \times g$ for $30 \mathrm{~min}$. Streptomycin solution was added to the extract to a final concentration of $1 \%$. After $30 \mathrm{~min}$, the precipitate was removed by centrifugation at $20,000 \times g$ for $20 \mathrm{~min}$. Ammonium sulfate was added to the supernatant to a final concentration of $40 \%$ saturation. The mixture was centrifuged and ammonium sulfate was further added to the supernatant to a final $65 \%$ saturation. The precipitate was dissolved in $5 \mathrm{ml}$ of starting buffer, and this solution was applied to a column $(3 \times 50 \mathrm{~cm})$ of Bio-Gel A$1.5 \mathrm{~m}$, and eluted with $50 \mathrm{mM}$ Tris- $\mathrm{HCl}$ buffer, $\mathrm{pH} 7.2$, containing $0.1 \mathrm{mM} \mathrm{MnCl}_{2}$. Fractions of $10 \mathrm{ml}$ were collected. The fractions having glutamine synthetase activity (No. 21 to No. 23) were applied to a TSK gel DEAE-5PW column (0.75 $\times 7.5 \mathrm{~cm}$, Tosoh, Tokyo, Japan) pre-equilibrated in the same buffer. The column was washed with a buffer containing $0.2 \mathrm{M} \mathrm{KCl}$ and developed with a linear $0.2-$ $0.5 \mathrm{M} \mathrm{KCl}$ gradient. The four-step purification of glutamine synthetase from $14 \mathrm{~g}$ of wet cells resulted in 75 -fold purification, with a yield of about $21 \%$. The purification of the enzyme by selective affinity chromatography with $5^{\prime}$-AMP Sepharose and Affi-gel blue, as described for the isolation of some other bacterial glutamine synthetase, was not suitable for alkalophilic Bacillus enzyme.

\section{RESULTS AND DISCUSSION}

\section{Homogeneity and subunit molecular weight}

The purified enzyme was subjected to SDS-PAGE. As shown in Fig. 1, a single band (lane 2) appeared upon staining with Coomassie brilliant blue. The subunit molecular weight of the alkalophilic Bacillus No. 170 was 50,000, the same value as that of the enzyme from B. subtilis (lane 1); however, it was smaller than the 52,000 $E$. coli enzyme (lane 3). The results shown in Fig. 1 are in good agreement with those of $B$. subtilis glutamine synthetase which was 444 amino acids long (50,205 Da), compared with 469 for $E$. coli $(51,823 \mathrm{Da})$ deduced from the nucleotide sequence of the cloned gene $(18,22)$. The molecular weight of alkalophilic Bacillus No. 170 glutamine synthetase was estimated to be 600,000 by gel filtration on Bio Gel A1.5 m, with $B$. subtilis glutamine synthetase as a standard.

\section{Divalent cation requirement}

In previous papers, we reported that the activity of $B$. subtilis and $B$. cereus glutamine synthetase was greatly enhanced by the addition of $\mathrm{Mn}^{2+}$ to the $\mathrm{Mg}^{2+}$-dependent assay mixture $(13,17)$. In $E$. coli glutamine synthetase, the divalent cation specificity is modulated by adenylylation/deadenylylation of the subunits, and $\mathrm{Mg}^{2+}$-dependent activity is inhibited by the addition of $\mathrm{Mn}^{2+}(21)$. The alkalophilic Bacillus glutamine synthetase is activated by either $\mathrm{Mn}^{2+}$ or $\mathbf{M g}^{2+}$; however, the maximum activity was seen when the ratio of $\mathrm{Mn}^{2+}$ /ATP was about 1 and the ratio of $\mathrm{Mg}^{2+} / \mathrm{ATP}$ was more than 2 (Fig. 2A). $\mathrm{Cd}^{2+}$-dependent activity 


\section{3 \\ kDa

Fig. 1. SDS-polyacrylamide slab gel electrophoresis of the glutamine synthetase purified from three bacteria on a $12.5 \%$ gel.

Lane 1, glutamine synthetase from Bacillus subtilis $(1 \mu \mathrm{g})$; lane 2, glutamine synthetase purified from alkalophilic Bacillus $(4 \mu \mathrm{g})$; lane 3 , glutamine synthetase from Escherichia coli $(1.5 \mu \mathrm{g})$.
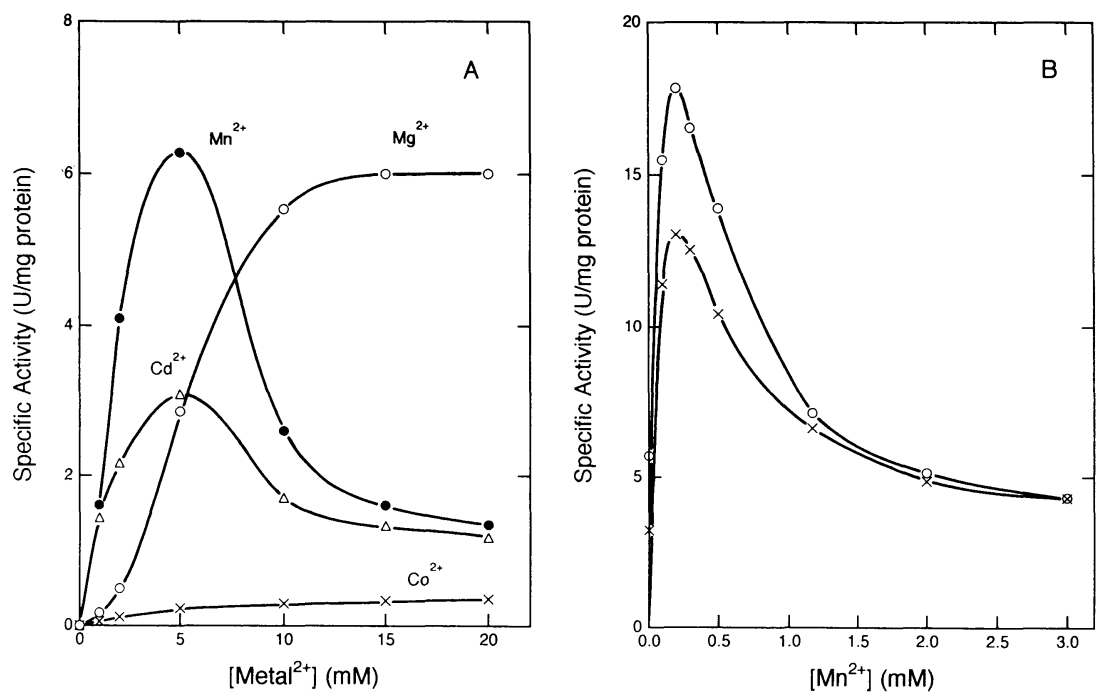

Fig. 2. Effect of increasing concentration of divalent cations on the velocity of alkalophilic Bacillus No. 170 glutamine synthetase activity.

(A) ATP concentration was constant at $5 \mathrm{~mm}$ in each assay mixture. (B) At two different $\mathrm{ATP} / \mathrm{Mg}^{2+}$ ratios $\left(\bigcirc, \mathrm{ATP} / \mathrm{Mg}^{2+}\right.$ was $5 \mathrm{~mm} / 20 \mathrm{mM} ; \times, \mathrm{ATP} / \mathrm{Mg}^{2+}$ was $5 \mathrm{mM} /$ $5 \mathrm{mM}$ ); and $\mathrm{Mn}^{2+}$ was increased to the indicated concentration. Activity measurements were performed by the standard biosynthetic assay at $30^{\circ} \mathrm{C}$, as mentioned under 'Materials AND Methods.' 
was similar to that of $\mathrm{Mn}^{2+}$ but $\mathrm{Co}^{2+}$-dependent activity was extremely small. In the presence of $20 \mathrm{mM} \mathrm{Mg}^{2+}$, the maximum biosynthetic activity was seen only when $0.2 \mathrm{mM} \mathrm{Mn}^{2+}$ was added to the assay mixture (Fig. 2B). The results suggested that the binding sites of $\mathrm{Mn}^{2+}$ and $\mathrm{Mg}^{2+}$ are separate from each other in the active site(s) of the enzyme. The $\mathrm{Cd}^{2+}$-dependent activity of the glutamine synthetase had unusual properties. The unique effects of the $\mathrm{Mg}^{2+} / \mathrm{Mn}^{2+}$ ratio on the catalytic activity were characteristic of Bacillus species glutamine synthetases.

\section{Inhibition by FSBA and iodoacetoamide}

To characterize the binding sites of $\mathrm{Mg}^{2+}$ and $\mathrm{Mn}^{2+}$, purified enzyme was modified by the ATP analog $5^{\prime}$-p-fluorosulfonyl benzoyladenosine (FSBA), and the effects on $\mathrm{Mg}^{2+}-, \mathrm{Mn}^{2+}$, and $\mathrm{Mg}^{2+}$ plus $\mathrm{Mn}^{2+}$-dependent activities were investigated. Figure $3 \mathrm{~A}$ shows the changes in catalytic activity of alkalophilic Bacillus glutamine synthetase by FSBA. $\mathrm{Mn}^{2+}$-dependent activity was decreased to $45 \%$ of its initial activity, in parallel to the loss of $\mathrm{Mn}^{2+}$ plus $\mathrm{Mg}^{2+}$-dependent activity in $60 \mathrm{~min}$, although $\mathrm{Mg}^{2+}$-dependent activity remained at $80 \%$ of its initial activity in the same period. These results suggest that the binding of FSBA to glutamine synthetase affected the $\mathrm{Mn}^{2+}$ - and $\mathrm{Mn}^{2+}$ plus $\mathrm{Mg}^{2+}$-dependent reactions
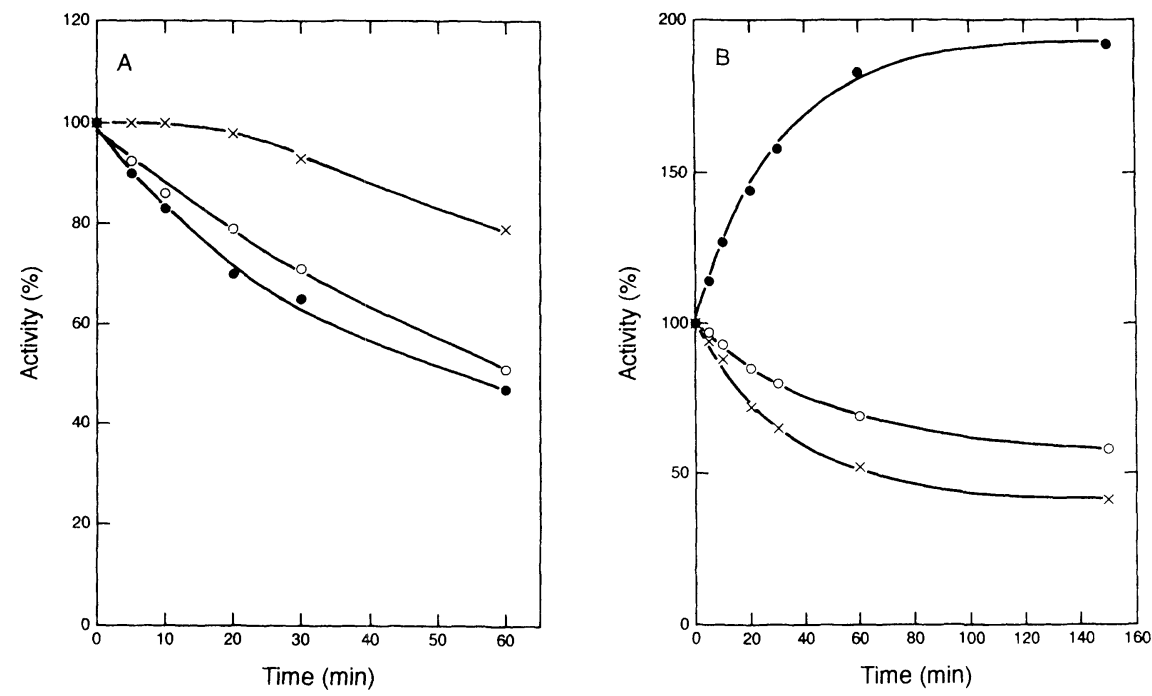

Fig. 3. Time course of inactivation by chemical modification of alkalophilic Bacillus No. 170 glutamine synthetase.

(A) Glutamine synthetase $(0.21 \mathrm{mg} / \mathrm{ml})$ was incubated with $26 \mu \mathrm{M}$ FSBA at $25^{\circ} \mathrm{C}$ in $50 \mathrm{mM}$ Tris- $\mathrm{HCl}$ buffer ( $\mathrm{pH} 7.2$ ). Each $\mathrm{Mn}^{2+}-(\bullet), \mathrm{Mg}^{2+}-(\times)$, and $\mathrm{Mg}^{2+}+$ $\mathrm{Mn}^{2+}$-dependent activity $(\bigcirc)$ was measured. (B) Glutamine synthetase $(0.21 \mathrm{mg} / \mathrm{ml})$ was incubated with $5 \mathrm{~mm}$ iodoacetoamide at $25^{\circ} \mathrm{C}$ in $50 \mathrm{~mm}$ Tris- $\mathrm{HCl}$ buffer ( $\mathrm{pH} \mathrm{9.0)}$. Each enzyme activity was assayed as in (A), by the method described under 'Materials AND Methods.' At time zero, $\mathrm{Mn}^{2+}-, \mathrm{Mg}^{2+}$, and $\mathrm{Mg}^{2+}+\mathrm{Mn}^{2+}$ dependent activity were $6.5,7.4$, and $14.0 \mu \mathrm{mol} / \mathrm{min} / \mathrm{mg}$ protein, respectively. 
Table 1. Effects of substrates on the inactivation of glutamine synthetase by FSBA.

\begin{tabular}{lc}
\hline \multicolumn{1}{c}{ Addition } & Residual activity $(\%)$ \\
\hline None & 51 \\
ATP $(5 \mathrm{~mm})$ & 97 \\
L-Glutamate $(50 \mathrm{~mm})$ & 22 \\
ATP $(5 \mathrm{~mm})+$ L-Glutamate $(50 \mathrm{~mm})$ & 99 \\
\hline
\end{tabular}

The enzyme was incubated with $0.1 \mathrm{~mm}$ FSBA at $25^{\circ} \mathrm{C}$ for $60 \mathrm{~min}$. The catalytic activity was measured in $\mathrm{Mg}^{2+}+\mathrm{Mn}^{2+}$-dependent activity. The results are expressed as a percentage relative to those of assays performed in the absence of FSBA.

more than the $\mathrm{Mg}^{2+}$-dependent reaction. As shown in Table 1, the inactivation by FSBA was completely protected by the addition of $5 \mathrm{mM}$ ATP, and was enhanced by the addition of $50 \mathrm{~mm}$ glutamate to the modification mixture. The effect of L-glutamate is significant because the binding of L-glutamate and ATP (E.S complex formation) involves strong synergism. These results suggest that the amino acid residue which reacts with FSBA is at or near the ATP binding site of the enzyme similar to other Bacillus enzymes. In each glutamine synthetase from $E$. coli or B. cereus, the modified amino acid residues are Lys 47 (19) or Lys 43 (15), respectively.

Modification of a cysteine residue with iodoacetoamide resulted in altered divalent cation dependency of the glutamine synthetases from $B$. cereus (17) and $B$. subtilis (2). In the modified enzyme, both the $\mathrm{Mg}^{2+}$-dependent and the $\mathrm{Mg}^{2+}$ plus $\mathrm{Mn}^{2+}$-dependent activities were decreased, but the $\mathrm{Mn}^{2+}$-dependent activity increased. These changes in catalytic activity were qualitatively similar to changes seen upon adenylylation of $E$. coli glutamine synthetase (21). Regulation by sulfhydryl group modification in vivo is difficult to establish, however Bacillus glutamine synthetases had a unique, reactive cysteine residue. The modified cysteine residue of $B$. cereus was Cys 306 (15) that is conserved in Bacillus glutamine synthetase $(16,18,22)$. As shown in Fig. $3 \mathrm{~B}, \mathrm{Mg}^{2+}-$ or $\mathrm{Mg}^{2+}$ plus $\mathrm{Mn}^{2+}$-dependent activity of the alkalophilic Bacillus enzyme decreased to $50 \%$ of the initial activity in $60 \mathrm{~min}$, similar to the activity of $B$. cereus glutamine synthetase (17), and the $\mathrm{Mn}^{2+}$-dependent activity increased to $180 \%$. This suggests that the binding sites of $\mathrm{Mn}^{2+}$ and $\mathrm{Mg}^{2+}$ are separate from each other in the active site of Bacillus glutamine synthetases and the cysteinyl residue which reacted with iodoacetoamide was also very close to the metal-ATP substrate-binding sites on the alkalophilic Bacillus glutamine synthetase.

\section{Kinetic properties}

Figure 4A shows the $\mathrm{pH}$ curves for the biosynthetic reactions using the purified enzyme with either $\mathrm{Mn}^{2+}, \mathrm{Mg}^{2+}$, or $\mathrm{Mg}^{2+}$ plus $\mathrm{Mn}^{2+}$ as divalent cations. The optimum $\mathrm{pH}$ varied considerably with the divalent cations used in the assay, however each profile was similar to that of other Bacillus enzymes. At pH 9.0, $\mathrm{Mg}^{2+}$ plus $\mathrm{Mn}^{2+}$-dependent activity of alkalophilic Bacillus enzyme was higher than 

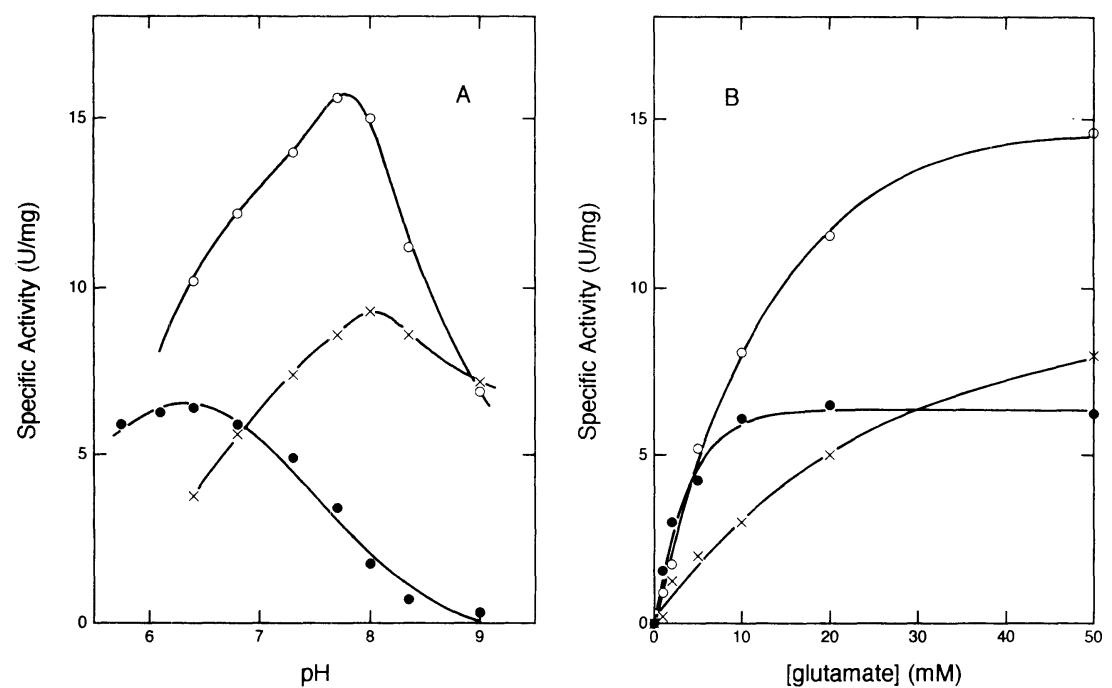

Fig. 4. Kinetic properties of alkalophilic Bacillus No. 170 glutamine synthetase.

The activity-pH profiles (A) and the glutamate saturation curves (B) was determined with $\mathrm{Mg}^{2+}(\times), \mathrm{Mn}^{2+}(\bullet)$, or $\mathrm{Mg}^{2+}+\mathrm{Mn}^{2+}(\bigcirc)$ as a divalent cation under the standard assay condition. Tris-maleate buffer (final concentration of $50 \mathrm{~mm}$ Tris and $50 \mathrm{~mm}$ maleic acid) adjusted to various $\mathrm{pHs}$ with $\mathrm{NaOH}$; the $\mathrm{pH}$ of the reaction mixture was measured.

that of $B$. cereus enzyme (13), but the optimum $\mathrm{pH}$ of both enzymes was near 7.8. These results suggest that the optimum $\mathrm{pH}$ of the enzymes from alkalophilic Bacillus does not always depend on their growth condition. Figure 4B shows the substrate saturation curves for glutamate with either $\mathrm{Mg}^{2+}-\mathrm{ATP}, \mathrm{Mn}^{2+}-\mathrm{ATP}$, or $\mathrm{Mg}^{2+}$ plus $\mathrm{Mn}^{2+}$-ATP, each of fixed concentration. The apparent $K_{\mathrm{m}}$ for each of the three substrates and $V_{\max }$ are shown in Table 2. In the $\mathrm{Mg}^{2+}$ plus $\mathrm{Mn}^{2+}$-dependent reaction, the $K_{\mathrm{m}}$ value for each of these three substrates was intermediate between those of the $\mathrm{Mn}^{2+}$ - and $\mathrm{Mg}^{2+}$-dependent reactions, and the $V_{\max }$ was higher than that for either $\mathrm{Mg}^{2+}$ or $\mathrm{Mn}^{2+}$. As shown in Fig. 2B, the activity of the enzyme was greatly enhanced by the addition of $\mathrm{Mn}^{2+}$ to the $\mathrm{Mg}^{2+}$-dependent assay mixture, and the highest $V_{\max }$ was obtained in the $\mathrm{Mn}^{2+}$ plus $\mathrm{Mg}^{2+}$-dependent assay (Table 2). This finding suggests that Bacillus species glutamine synthetases are rigorously controlled by the intracellular concentration of divalent cations, in common with glutamine, AMP and other metabolites. From a physiological point of view, the $\mathrm{Mg}^{2+}$ plus $\mathrm{Mn}^{2+}$-dependent activity was most important for this Bacillus (4).

\section{Effect of feedback inhibitors}

In contrast to the $E$. coli enzyme, $B$. subtilis glutamine synthetase is directly inhibited by glutamine. The intracellular level of glutamine is the most important factor in determining $B$. subtilis glutamine synthetase activity (3). Hence, the 
Table 2. Kinetic constants of glutamine synthetase from alkalophilic Bacillus No. 170.

\begin{tabular}{cccc}
\hline & \multicolumn{3}{c}{ Biosynthetic activity } \\
\cline { 2 - 4 } & $\mathrm{Mg}^{2+}$-assay & $\mathrm{Mn}^{2+}$-assay & $\mathrm{Mg}^{2+}+\mathrm{Mn}^{2+}$-assay \\
\hline$K_{\mathrm{m}}(\mathrm{mM})$ & & & 1.03 \\
$\mathrm{ATP}$ & 1.76 & 0.260 & 10.4 \\
$\mathrm{Glutamate}$ & 29.6 & 1.31 & 0.50 \\
$\mathrm{NH}_{3}$ & 0.280 & 1.10 & 16.5 \\
$V_{\max }(\mu \mathrm{mol} / \mathrm{min} / \mathrm{mg})$ & 11.1 & 6.88 & \\
\hline
\end{tabular}

a $\mathrm{Mn}^{2+}: \mathrm{Mg}^{2+}=1: 100$.

The apparent $K_{\mathrm{m}}$ values were obtained from double reciprocal plots of velocity versus substrate concentration.

Table 3. Effect of feedback inhibitors upon biosynthetic activity of glutamine synthetase.

\begin{tabular}{lccc}
\hline & \multicolumn{3}{c}{ Remaining activity (\%) } \\
\cline { 2 - 4 } Inhibitor (mM) & $\mathrm{Mg}^{2+}$ & $\mathbf{M n}^{2+}$ & $\mathbf{M g}^{2+}+\mathbf{M n}^{2+}$ \\
\hline None & 100 & 100 & 100 \\
Alanine (5) & 100 & 49 & 87 \\
Glycine (5) & 94 & 55 & 91 \\
Serine (5) & 89 & 71 & 99 \\
Glutamine (1) & 46 & 93 & 56 \\
AMP (0.2) & 32 & 85 & 54 \\
\hline
\end{tabular}

The enzyme activity was assayed by standard methods described under 'MATERIALS AND Methods.' One hundred percent activity of $\mathrm{Mg}^{2+}-, \mathrm{Mn}^{2+}$, and $\mathrm{Mg}^{2+}+\mathrm{Mn}^{2+}$-dependent reactions were $6.2,7.5$ and $12.9 \mu \mathrm{mol} / \mathrm{min} / \mathrm{mg}$ protein, respectively. The enzyme was not preincubated with the inhibitors.

effects of various end-products of glutamine synthetase were examined under the three sets of divalent cation assays with all substrates in a saturated condition. The results of five compounds which appreciably inhibited the activities of the alkalophilic Bacillus glutamine synthetase are summarized in Table 3. Glutamine and AMP were the most potent inhibitors at a physiologically low concentration for the $\mathrm{Mg}^{2+}$-dependent activity of the enzyme, but the enzyme's sensitivity to the feedback inhibitors was altered by the divalent cation present during the assay. When $\mathrm{Mg}^{2+}$ plus $\mathrm{Mn}^{2+}$ was used as the divalent cation, the enzyme activity became less sensitive to each inhibitor. These catalytic properties of alkalophilic Bacillus glutamine synthetase are compatible with those of B. cereus (12) and B. subtilis (13) enzyme.

\section{Determination of $\mathrm{NH}_{2}$-terminal amino acid sequence}

The $\mathrm{NH}_{2}$-terminal amino acid sequences of the glutamine synthetase purified from alkalophilic Bacillus was determined by automated Edman degradation with an Applied Biosystems sequencer system in 20 steps. The fifth amino acid remained undetermined, since small quantities of PTP-amino acids corresponding to Arg and Lys were found. A comparison of the $\mathrm{NH}_{2}$-terminal amino acid sequence of glutamine synthetase from alkalophilic Bacillus and eleven other prokaryotes is 


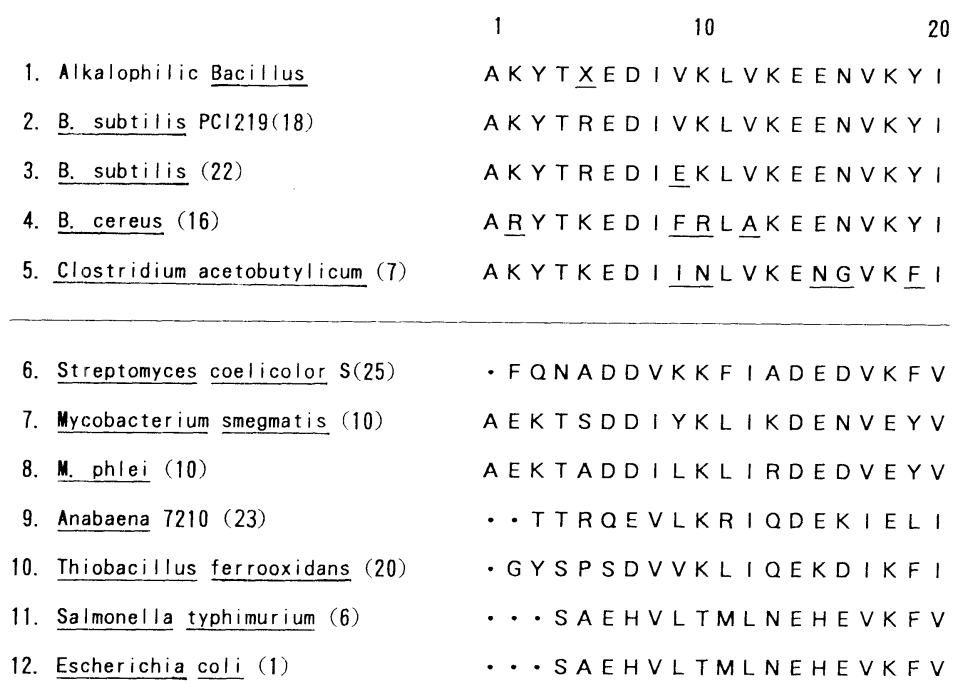

Fig. 5. $\mathrm{NH}_{2}$-terminal amino acid sequence.

The line may be conveniently divided into two groups: those above the line are spore-forming bacteria, and those below are subject to regulation by adenylylation except Anabaena.

shown in Fig. 5. Although the analysis was limited, the sequence of alkalophilic Bacillus glutamine synthetase was in agreement with the sequence from two strains of $B$. subtilis and $B$. cereus glutamine synthetase $(16,18,22)$, and demonstrated high homology with the enzyme from Clostridium acetobutylicum (7). The sequence of Bacillus glutamine synthetase is not similar to those from the three other Grampositive bacteria, such as Streptomyces (25) and Mycobacterium (10), nor to those from Gram-negative bacteria. Although the activity of Anabena glutamine synthetase can not be regulated, the other six glutamine synthetase activities can be regulated by adenylylation/deadenylylation similar to the $E$. coli glutamine synthetase. The results of an Ouchterlony double immunodiffusion experiment of alkalophilic Bacillus glutamine synthetase versus antisera of $B$. subtilis glutamine synthetase showed high reactivity similar to that of each glutamine synthetase from B. subtilis or B. cereus (13).

In conclusion, it is clear that glutamine synthetases from Bacillus species do not appear to have a global regulation system of nitrogen metabolism as demonstrated in $E$. coli $(5,11,14,21,24)$, though they can sporulate when deprived of a rapidly metabolizable nitrogen source. Apparently, many properties of the alkalophilic Bacillus enzyme are dependent on the divalent cation used for activation, similar to the enzymes from $B$. subtilis and B. cereus. Thus, the $\mathrm{Mg}^{2+} / \mathrm{Mn}^{2+}$ ratios may be important in the regulation of the Bacillus glutamine synthetase under physiological conditions. 
We thank Dr. K. Horikoshi for kindly providing the alkalophilic Bacillus Strain 170, and permitting us to use his automated amino acid sequencer.

\section{REFERENCES}

1) Colombo, G. and Villafranca, J. J., Amino acid sequence of Escherichia coli glutamine synthetase deduced from the DNA nucleotide sequence. J. Biol. Chem., 261, 10587-10591 (1986).

2) Deuel, T. F., Bacillus subtilis glutamine synthetase. Specific catalytic changes associated with limited sulfhydryl modification. J. Biol. Chem., 246, 599-605 (1971).

3) Deuel, T. F. and Stadtman, E. R., Some kinetic properties of Bacillus subtilis glutamine synthetase. J. Biol. Chem., 245, 5205-5213 (1970).

4) Eisenstadt, E., Fisher, S., Der, C.-L., and Silver, S., Manganese transport in Bacillus subtilis W23 during growth and sporulation. J. Bacteriol., 113, 1363-1372 (1973).

5) Heinrikson, R. L. and Kingdon, H. S., Primary structure of Escherichia coli glutamine synthetase II. The complete amino acid sequence of a tryptic heneicosa-peptide containing covalently bound adenylic acid. J. Biol. Chem., 246, 1099-1106 (1971).

6) Janson, C. A., Kayne, P. S., Almassy, R. J., Grunstein, M., and Eisenberg, D., Sequence of glutamine synthetase from Salmonella typhimurium and implications for the protein structure. Gene, 46, 297-300 (1986).

7) Janssen, P. J., Jones, W. A., Jones, D. T., and Woods, D. R., Molecular analysis and regulation of the $g \ln \mathrm{A}$ gene of the Gram-positive anaerobe Clostridium acetobutylicum. J. Bacteriol., 170, 400-408 (1988).

8) Kato, C., Kudo, T., Watanabe, K., and Horikoshi, K., Extracellular production of Bacillus penicillinase by Escherichia coli carrying pEAP2. Eur. J. Appl. Microbiol. Biotechnol., 18, 339-343 (1983).

9) Kimura, K., Sugano, S., Funae, A., and Nakano, Y., Characterization of Bacillus subtilis glutamine synthetase by limited proteolysis. J. Biochem., 110, 526-531 (1991).

10) Kimura, K., Suzuki, H., and Nakano, Y., Physical and chemical characterization of glutamine synthetase purified from Mycobacterium phlei. J. Biochem., 105, 648-652 (1989).

11) Magasanik, B., Genetic control of nitrogen assimilation in bacteria. Annu. Rev. Genet., 16, 135168 (1982).

12) Matsuoka, K., A study on glutamine synthetase from Bacillus subtilis. Ph.D. Thesis, Rikkyo (St. Paul's) University, Tokyo (1985).

13) Matsuoka, K., Kurebayashi, T., and Kimura, K., Regulation and properties of glutamine synthetase purified from Bacillus cereus. J. Biochem., 98, 1211-1219 (1985).

14) Miranda-Rios, J., Sanchez-Pescador, R., Urdea, M., and Covarrubias, A. A., The complete nucleotide sequence of the glnALG operon of Escherichia coli K12. Nucl. Acids Res., 15, 27572770 (1987).

15) Nakano, Y., Itoh, M., Tanaka, E., and Kimura, K., Identification of the reactive cysteinyl residue and ATP binding site in Bacillus cereus glutamine synthetase by chemical modification. J. Biochem., 107, 180-183 (1990).

16) Nakano, Y., Kato, C., Tanaka, E., Kimura, K., and Horikoshi, K., Nucleotide sequence of the glutamine synthetase gene $(g \ln \mathrm{A})$ and its upstream region from Bacillus cereus. J. Biochem., 106, 209-215 (1989).

17) Nakano, Y. and Kimura, K., Independent bindings of $\mathrm{Mn}^{2+}$ and $\mathrm{Mg}^{2+}$ to the active site of $B$. cereus glutamine synthetase. Biochem. Biophys. Res. Commun., 142, 475-482 (1987).

18) Nakano, Y., Tanaka, E., Kato, C., Kimura, K., and Horikoshi, K., The complete nucleotide sequence of the glutamine synthetase gene $(g \ln \mathrm{A})$ of Bacillus subtilis. FEMS Microbiol. Lett., 57, 81-86 (1989).

19) Pinkofsky, H. B., Ginsburg, A., Reardon, I., and Heinrikson, R. L., Lysyl residue 47 is near the 
subunit ATP-binding site of glutamine synthetase from Escherichia coli. J. Biol. Chem., 259, 96169622 (1984).

20) Rawlings, D. E., Jones, W. A., O'Neill, E. G., and Woods, D. R., Nucleotide sequence of the glutamine synthetase gene and its controlling region from the acidophilic autotroph Thiobacillus ferrooxidans. Gene, 53, 211-217 (1987).

21) Stadtman, E. R. and Ginsburg, A., The glutamine synthetase of Escherichia coli: Structure and control. In The Enzymes, Vol. 10, 3rd ed., ed. by Boyer, P. D., Academic Press, New York (1974), p. 755-807.

22) Strauch, M. A., Aronson, A. I., Brown, S. W., Schreier, H. J., and Sonenshein, A. L., Sequence of the Bacillus subtilis glutamine synthetase gene region. Gene, 71, 257-265 (1988).

23) Tumer, N. E., Robinson, S. J., and Haselkorn, R., Different promoters for the anabaena glutamine synthetase gene during growth using molecular or fixed nitrogen. Nature, 306, 337-342 (1983).

24) Tyler, B., Regulation of the assimilation of nitrogen compounds. Annu. Rev. Biochem., 47, 11271162 (1978).

25) Wray, L. V., Jr. and Fisher, S. H., Cloning and nucleotide sequence of the streptomyces coelicolor gene encoding glutamine synthetase. Gene, 71, 247-256 (1988). 